\title{
Evaluation of the Fluorescence of Composite Resins Under an Ultraviolet Light Source
}

\author{
Evaluación de la Fluorescencia de Resinas \\ Compuestas Bajo una Fuente de Luz Ultravioleta
}

\begin{abstract}
Ana Larisse Carneiro Pereira1; Larissa Sgarbosa de Araújo Matuda³; Leonardo Gomes de Lima²; João Marcos Ferreira de Lima Silva ${ }^{4}$; Lorem Krsna de Morais-Sousa; Jefferson David Melo de Matos $^{5}$; John Eversong Lucena de Vasconcelos ${ }^{6} \&$ Cássio Rocha Medeiros $^{7}$
\end{abstract}

PEREIRA, A. L. C.; MATUDA, L. S. A.; LIMA, L. G.; SILVA, M. F. L.; MORAIS-SOUSA, L. K.; MATOS, J. D. M.; VASCONCELOS, J. E. L. \& MEDEIROS, C. R. Evaluation of the fluorescence of composite resins under an ultra violet light source. Int. J. Odontostomat., 12(3):252-261, 2018.

ABSTRACT: The aim of this research is to compare the fluorescence of different trademarks of composite resins under ultraviolet light, indicating through the optical characteristics the restorative materials that best mimic the properties of dental fluorescence. In this study, nine composite resin trademarks of EA2 color were evaluated, and ten test samples were prepared for each material, totalizing ninety specimens. The specimens were produced from a bipartite aluminium matrix $(10 \times 2 \mathrm{~mm})$, and then stored for $24 \mathrm{~h}$ in tubes of radiographic films, immersed in distilled water and after $48 \mathrm{~h}$ it were polished. A blind-type study (four evaluators) was used and the samples were analyzed in a dark wooden chamber where it was coupled two black lamps. In the data collection phase, the Kolmogorov-Smirnov normality test, ANOVA and Post Hoc of Tukey were used (adopting a significance level of 0.05). It was noted that the composite resin of the trademark Ultrafill was more fluorescent and Luna was statistically less fluorescent than all other materials, while Opallis and Tetric were superior to Glacier. There was no significant statistical difference among the composite resins Premissa, Point 4, Llis and Premium.

KEY WORDS: fluorescence, esthetics, dental, ultraviolet rays.

\section{INTRODUCTION}

In 1801, it was realized that the ultraviolet light had the ability to produce a type of brightness in both materials and tissues, and since then the relationship between the light spectrum and its effects on the living organism has been studied (Rudd et al., 1967). Stiibel, in 1911, carried out the first studies related to fluorescence in natural teeth, concluding that the teeth presented white-blue fluorescent properties when exposed to the low intensity radiation of the ultraviolet rays. This characteristic makes the natural teeth whiter and brighter in daylight, giving it an aspect of vitality and naturalness (Monsénégo et al., 1993).
Fluorescence is a phenomenon capable of absorbing light energy of ultraviolet origin and reemit it in the visible light spectrum, in the form of blue-violet light (Terry et al., 2002). This means that the absorption of electromagnetic waves invisible to the human eye is converted by the body irradiated with ultraviolet light, which reemits it as visible energy (Villarroel et al., 2004).

This phenomenon occurs through the absorption of ultraviolet rays, in the presence of wavelengths between 330 and $390 \mathrm{~nm}$, which are emitted by sunlight and as a consequence of this action, the photosensitive

\footnotetext{
${ }^{1}$ Post Graduate Student - Masters Degree Program in Dentistry Clinic, Department of Prosthodontics, Universidade Federal do Rio Grande do Norte UFRN, Natal - RN, Brasil.

${ }^{2}$ Graduate in Dentistry, Centro Universitário UNILEÃO, Juazeiro do Norte - CE, Brazil.

${ }^{3} \mathrm{Ph} . \mathrm{D}$ in Dentistry, Department of Restorative Dentistry, Universidade Estadual de Campinas UNICAMP, Araçatuba - SP, Brazil.

${ }^{4}$ Professor of Biostatistics, Department of Dentistry, Centro Universitário UNILEÃO, Juazeiro do Norte - CE, Brazil.

${ }^{5}$ Post Graduate Student - Masters Degree Program, Department of Prosthodontics, Universidade Estadual Paulista Júlio de Mesquita Filho UNESP, São José dos Campos - SP, Brazil.

${ }^{6}$ Professor of Oral Implantology, Department of Dentistry, Centro Caririense de Pós-Graduação CECAP, Juazeiro do Norte - CE, Brazil. ${ }^{7} \mathrm{Ph} . \mathrm{D}$ in Dentistry, Department of Restorative Dentistry, Universidade Pernambuco, UPE, Recife-PE, Brazil.
} 
PEREIRA, A. L. C.; MATUDA, L. S. A.; LIMA, L. G.; SILVA, M. F. L.; MORAIS-SOUSA, L. K.; MATOS, J. D. M.; VASCONCELOS, J. E. L. \& MEDEIROS, C. R. Evaluation of the fluorescence of composite resins under an ultra violet light source. Int. J. Odontostomat., 12(3):252-261, 2018.

components present in both dentin and enamel are excited (Kosovel \& Weber, 1976). The teeth, for example, when exposed to the light source with ultraviolet components (black light), reemit at a greater wavelength, between 400 and $500 \mathrm{~nm}$, corresponding to the blue spectral band (Panzeri et al., 1977; Sensi et al., 2006; Meller \& Klein, 2012). However, the fluorescence may also manifest itself in another way, the absorption of bluish light and in the emission of light with a longer wavelength, which can be reemitted in yellowish color, instead of blue-violet (McPhee, 1985; McLaren, 1997).

The body that will receive the radiation absorbs the incoming light and passes to a more energetic orbital. When it returns to its state or natural orbit, it emits light. The ultraviolet light containing more energy than visible light, when it acts on a body, it excites the atoms of the structures involved. When the state of excitation of these atoms decreases, even if still far from the condition considered natural, the lower energy radiation is emitted as visible light, resulting in the fluorescence, a fact also explained as "Stokes's Law" (Priest \& Lindke, 2000).

Fluorescence belongs to the family of photoluminescence processes, in which case, the molecules can emit light through electronically excited states. This state can be created through three mechanisms: physical, mechanical or chemical (Melo et al., 2005). Photoluminescence is defined as the ability of bodies to emit certain types of light when subjected to invisible ultraviolet rays. It can be divided into two bodies: phosphorescent (bodies that have the ability to continue to emit visible light even after the remotion of the ultraviolet rays) and fluorescents (bodies that emit visible light only during exposure to ultraviolet rays) (Vanini \& Mangani, 2001).

In the process of light transmission by the dental structure, there are properties that are related to the naturalness of this structure, which are: transmittance, absorbance and fluorescence (Lefever et al., 2010). The transmittance is the amount of light that can penetrate and be transmitted by the material or body. This property allows the material to return the dental structure's its natural appearance, which gives the sensation of visual depth in the area where the material was received. The absorbance, that is the inverse property, has as main characteristic to prevent the total passage of light by the restoration, in order to minimize the negative effect of the dark background of the mouth.
The enamel and dentin interrelation, in the natural tooth, determines their color through the processes of reflection and refraction of light. In view of this dynamism that may exist in these processes, restorative materials need to have similar optical properties of the dental structure, making the restorations almost imperceptible (Busato et al., 2006). The dentin and the enamel, respectively, differ in fluorescence, once that the former is brighter and bluish, while the latter has a decrease in fluorescence in areas of white lesions (Benedict, 1928).

In this context, the search for a perfect smile as well as the advancement of researches has boosted the technological development of materials even more aesthetic and compatible with the natural teeth. Therefore, the accomplishment of this research will contribute to the knowledge of the fluorescent characteristics of the composite materials, in order to demonstrate among the materials under study, those considered ideal for use in anterior restorations.

This study aims to compare the fluorescence of different trademarks of composite resins under ultraviolet light sources, indicating through the optical characteristics the restorative materials that best mimic the properties of dental fluorescence

\section{MATERIAL AND METHOD}

In this study, 9 (nine) trademarks of composite resin in the EA2 color (Table I) were evaluated, and 10 (ten) specimens were prepared for each material $(n=$ 10), totalizing 90 (ninety) specimens.

Preparation of test samples. The sample tests were made from a bipartite aluminium matrix containing an orifice with the following dimensions: $10 \mathrm{~mm}$ in diameter and $2 \mathrm{~mm}$ in thickness, as shown in Fig. 1.

The composite resin was inserted in a single increment inside the orifice of the aluminium matrix with the aid of titanium spatulas (Thompson, $n^{\circ} 2$ and $n^{\circ} 5$ - Millennium - Sao Paulo / Brazil). Prior to the insertion of the resin increment, the bipartite matrix was lubricated with water-soluble lotion $(\mathrm{KY}$, Johnson \& Johnson, Brazil). The insertion was performed on a rectangular glass plate with a smooth-polished surface (Golgran - São Caetano do Sul / Brazil). After the insertion of the composite resin, a polyester matrix strip 
(TDV - Pomerode / Brazil) was placed on the unpolymerized resin. A glass slide $(8 \mathrm{~cm}$ long and 2 $\mathrm{cm}$ thick) was placed on the polyester strip, exerting a slight manual pressure, in order to obtain a better surface smoothness of the resin as well as oxygen isolation. The use of the glass slide also served to standardize the distance of the resin to the light source, limiting it to $2.0 \mathrm{~mm}$ (Fig. 2).
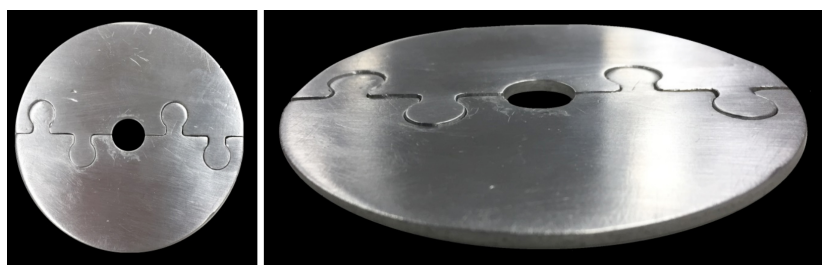

Fig. 1. Aluminium matrix with central orifice of dimensions $10 \times 2 \mathrm{~mm}$

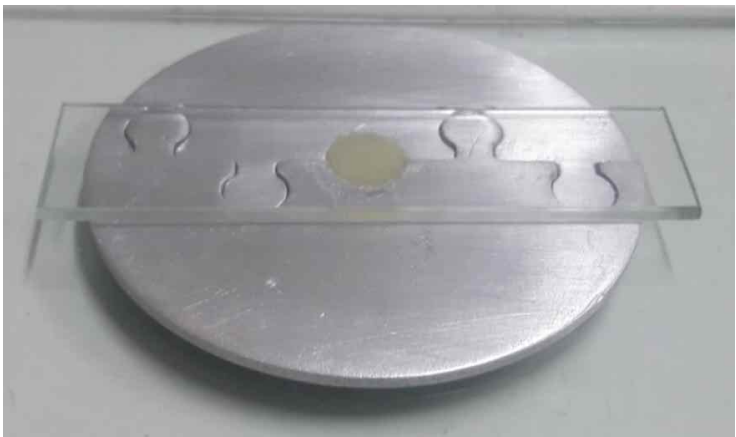

Fig. 2. Confection of the specimens.

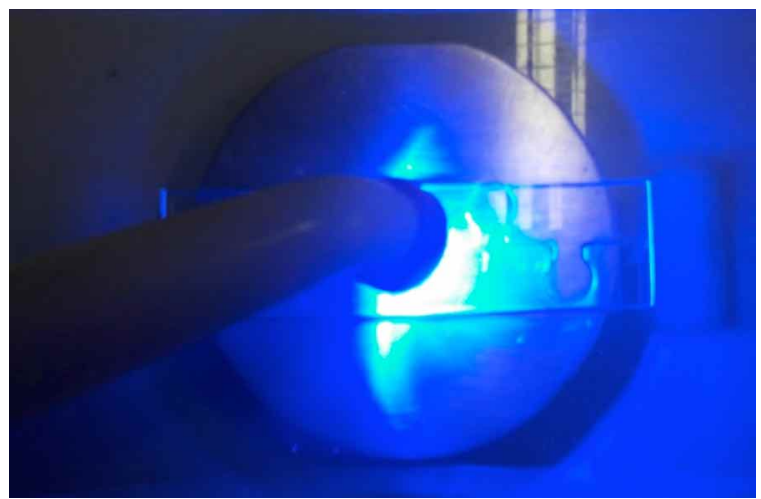

Fig. 3. Photopolimerization of the material for the confection of the specimens.

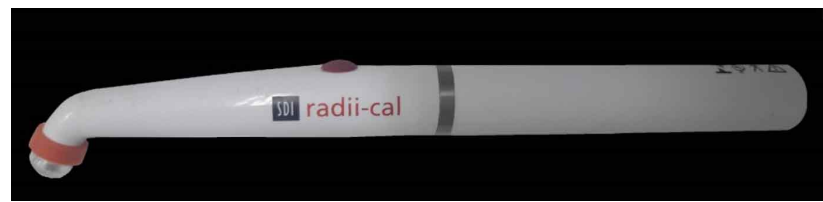

Fig. 4. Radii-Cal light curing device (SDI), which was kindly provided by the Centro Caririense de Pós-graduação CECAP.
The composite resin was cured for 40 seconds (Fig. 3) using a photopolymerizer (Radii-Cal - SDI), which was the same for all specimens (Fig. 4). This device had its power measured by a radiometer (a digital instrument used to measure the intensity of the visible light emitted by photopolymerization units) (Fig. 5). To each specimen prepared, the matrix was cleaned with $70 \%$ alcohol and again lubricated with water-soluble lotion, the objective of this was to avoid that the traces of one material were incorporated into the other.

After that, the sample tests were stored for 24 hours in tubes of radiographic films, then immersed in distilled water and labeled with a predetermined code for each trademark of composite resin utilized (Fig. 6). After $48 \mathrm{~h}$ of preparation of the test samples, possible excesses were removed through a surgical scalpel blade $\mathrm{n}^{\circ} 12$, and then the samples were polished with Sof-Lex (3M) Pop-on discs (Fig. 7). Each disc was used

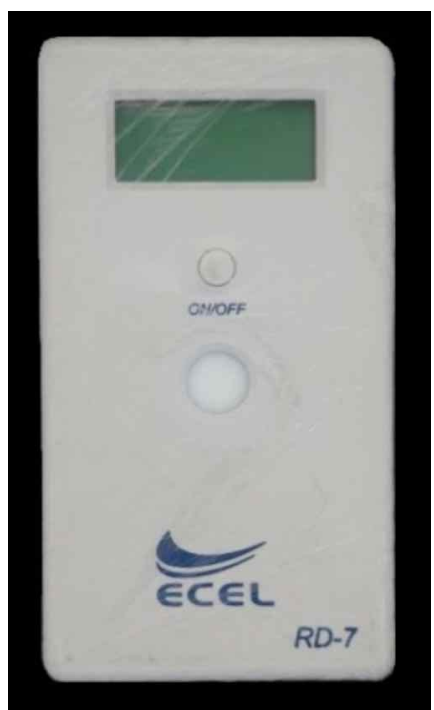

Fig. 5. Radiometer device model ECEL / RD-7 (Ribeirão Preto - São Paulo), which kindly provided by the Centro Universitário Doutor Leão Sampaio - UNILEÃO.

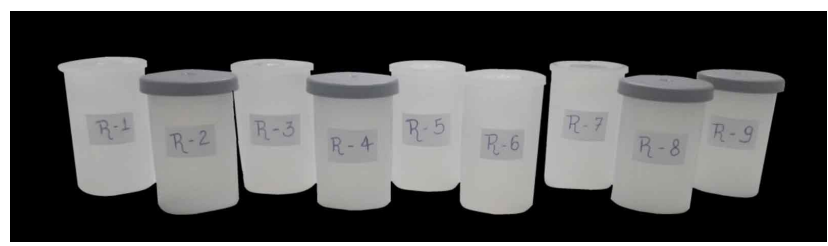

Fig. 6. Storage and labeling of the specimens in photographic film tubes. 
for 1 (one) minute, following the sequence suggested by the manufacturer, in descending order of granulation, in order to remove a rich organic matrix layer. After the finishing and polishing discs were applied, the specimens were placed in an ultrasonic device, in order to remove the residues released by the discs on the surface of the specimens.

Analysis of the sample tests. For the analysis of the samples, an ultraviolet light chamber was made - UV of wood, $30 \mathrm{~cm}$ width, $10 \mathrm{~cm}$ high and $40 \mathrm{~cm}$ length (Fig. 8), which was covered with matte black to avoid reflection of other colors besides ultraviolet. Inside the chamber were attached two ultraviolet light emitting lamps (black light) of the trademark Tashibra (5w) (Fig. 9) and was marked a fixed point on the chamber floor, in order to determine the fixation of the sample cards and provide a visualization's axis to the evaluators. The analysis was performed in a totally dark room, in order to avoid the interference of external luminosity.

After that, ten (10) plates of wood $(8.1 \mathrm{~cm}$ width and $6.3 \mathrm{~cm}$ length), coated with black matte, were prepared for analysis of the specimens. Each plate was identified by a letter (A, B, C, D, E, F, G, H, I and J) and presented a grid with 9 divisions that received numbers $(1,2,3,4,5,6,7,8,9)$. In this way cards were created where each of the nine resins evaluated received a position (A1, A2, A3, up to A9). For each card (A, B, C, etc.), the composite resins were changed in order to achieve a better randomization (Fig. 10).

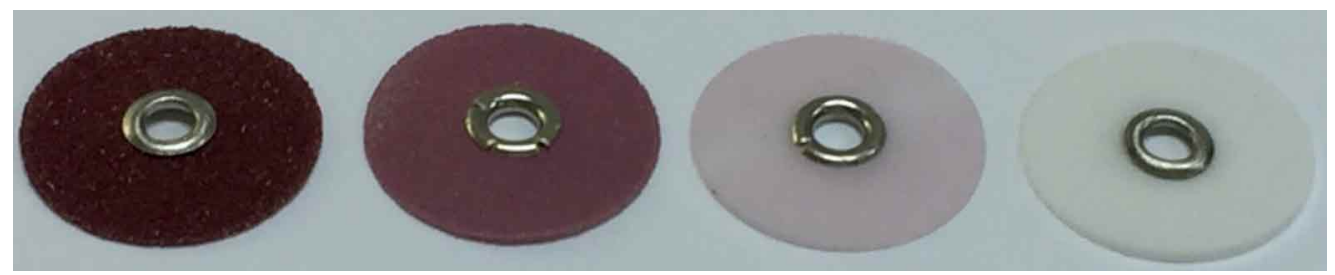

Fig. 7. Sequence of use of the Sof-Lex (3M) Pop-on discs in the polishing phase of the specimens.
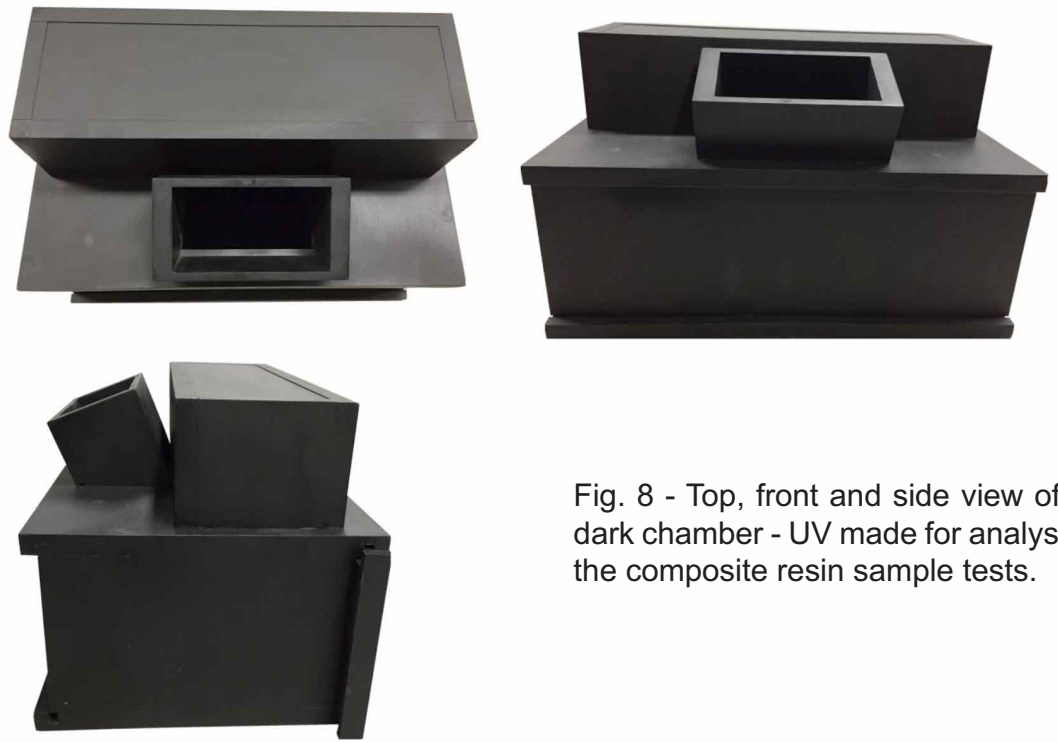

Fig. 8 - Top, front and side view of the dark chamber - UV made for analysis of the composite resin sample tests.
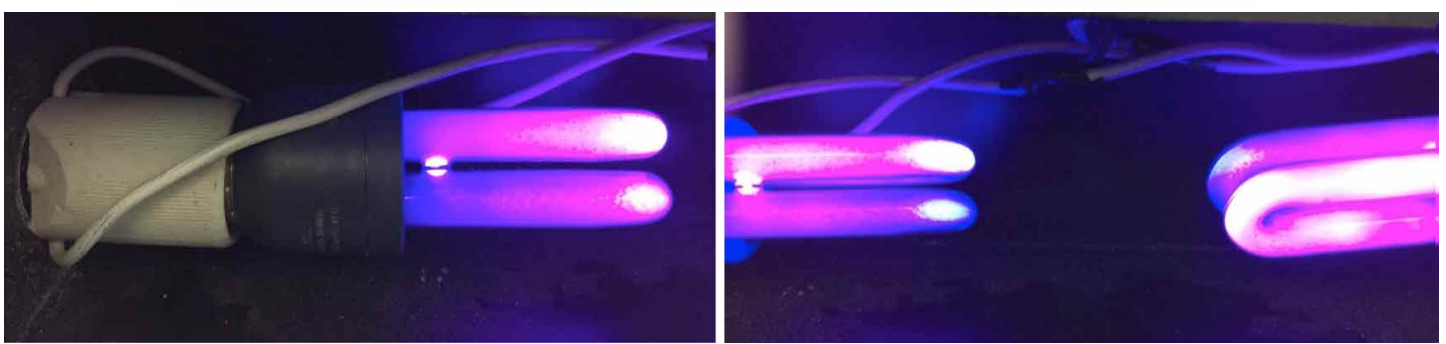

Fig. 9. Electrical system installed in the interior / upper compartment of the chamber - UV. 
PEREIRA, A. L. C.; MATUDA, L. S. A.; LIMA, L. G.; SILVA, JOÃO, M. F. L.; MORAIS-SOUSA, L. K.; MATOS, J. D. M.; VASCONCELOS, J. E. L. E. \& MEDEIROS, C. R. Evaluation of the fluorescence of composite resins under an ultra violet light source. Int. J. Odontostomat., 12(3):252-261, 2018.

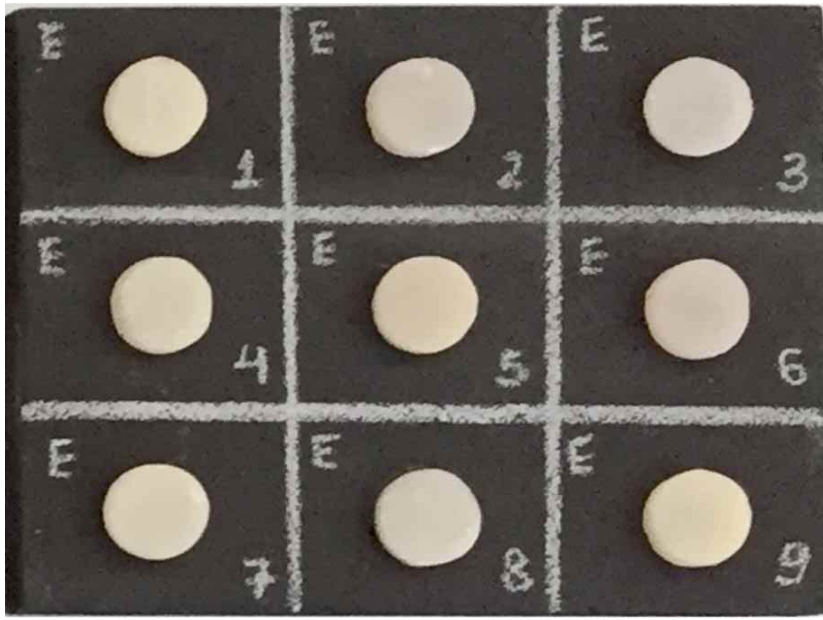

Fig. 10.- The sample cards made for the fixation of the specimens and disposition in the determined order.

For the analysis, a blind-type experiment was utilized, in which the evaluator was unaware of the trademark of the composite resin that was being evaluated. The order of disposition of the specimens on each card was pre-determined, with the template being in the sole possession and knowledge of the researcher.

The study selected four (4) evaluators for analysis of the specimens. The prerequisites for the evaluators were that they should work in a dental clinic, be a professor in the course of Dentistry of any location in Brazil and work with color selection of resin composites. Initially, the evaluators underwent a visual and theoretical calibration on the subject in question, which consisted of a verbal explanation on the subject in question as well as appreciation of figures with resinous materials under an ultraviolet light source. Each evaluator received a form to be filled in with the responses they observed. They were instructed to classify the degree of fluorescence emitted by the test specimens in decreasing order, using equal $(=)$ or greater than (>) signs (Table II).

The sample cards were displayed to the evaluators under an ultraviolet light source, following the same order for all of them. The sequence of display of the sample cards followed the order of alphabetic letters utilized in the identification, where at each exchange of sample cards, the evaluator was instructed to wait one (1) min, avoiding a biased evaluation of the eye, resulted by the fluorescent effect in the visual optics. The specimens were submitted to an ultraviolet light chamber and a fluorescence disparity

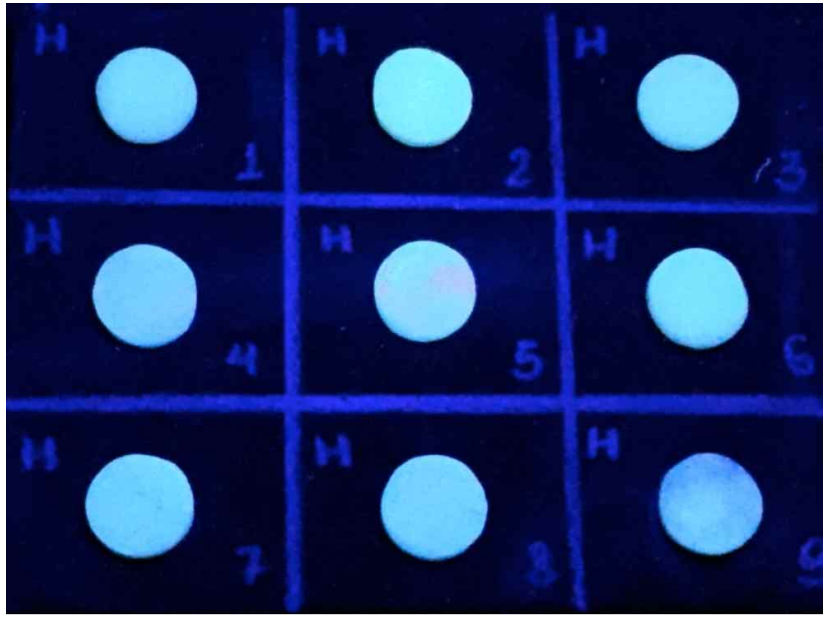

Fig. 11. Sample card under ultraviolet light source, showing the different fluorescence levels of the resinous materials at the time of the analysis.

was observed visually among the nine trademarks of resin composite utilized in the research (Fig. 11).

Analysis of the data. From the response cards provided by the evaluators, scores were assigned between 9 and 1 as a function of the perceived fluorescence, with these values registered in a decreasing way, from the left to the right, so that the most fluorescent specimen received a score of 9 (nine) while the less fluorescent score 1 (one). When the equal sign $(=)$ was identified between two or more test samples in sequence, which suggests that there is an equivalence in the perceived fluorescence level, the highest and lowest values of the test sample sequence were considered by calculating a mean and assigning this mean value for all test samples evaluated as equivalents of the same sequence.

Example: PREMISSA (9)> GLACIER $(6,5)=$ $\operatorname{LLIS}(6,5)=$ TETRIC $(6,5)=$ OPALLIS $(6,5)>$ PREMIUM (3) = POINT 4 (3) = ULTRAFILL > LUNA (1)

From the registered scores, it was considered the most fluorescent the material that presented the highest mean value, it was verified if there were statistical differences in the patterns of responses among the evaluators and the mean values between the materials were compared. For this study, the Kolmogorov-Smirnov normality test was performed to compare the responses provided by the evaluators, and the ANOVA test, to evaluate if the sample layout on the sample cards interfered with the analysis, followed then by the Tukey Post Hoc test, in order to express if there were statistically significant differences 
PEREIRA, A. L. C.; MATUDA, L. S. A.; LIMA, L. G.; SILVA, JOÃO, M. F. L.; MORAIS-SOUSA, L. K.; MATOS, J. D. M.; VASCONCELOS, J. E. L. E. \& MEDEIROS, C. R. Evaluation of the fluorescence of composite resins under an ultra violet light source. Int. J. Odontostomat., 12(3):252-261, 2018.

Table I. Resin composites that were utilized in the experiment.

\begin{tabular}{llll}
\hline Code & Trademark & Manufacture & Initials \\
\hline R-1 & Glacier & SDI & GL \\
R-2 & Llis & FGM & LLIS \\
R-3 & Luna & SDI & LUNA \\
R-4 & Opallis & FGM & OP \\
R-5 & Point 4 & KERR & P4 \\
R-6 & Premissa & KERR & PR \\
R-7 & Premium & COLTENE & NT \\
R-8 & Tetric N-Cream & IVOCLAR & TETRIC \\
R-9 & Ultrafill & BIODINÂMICA & ULTRA \\
\hline
\end{tabular}

Table II. Model of the answer sheet provided by the evaluator.

\begin{tabular}{|c|c|c|c|c|c|c|c|c|c|c|c|c|c|c|c|c|c|}
\hline T1 & A3 & $>$ & A2 & $=$ & A1 & $=$ & A9 & $=$ & A5 & $=$ & A8 & $>$ & A7 & $>$ & A4 & $=$ & A6 \\
\hline T2 & B3 & $>$ & B1 & $=$ & B9 & $>$ & B5 & $=$ & B2 & $=$ & B6 & $=$ & B7 & $=$ & B8 & $=$ & B4 \\
\hline$\Gamma 3$ & C2 & $=$ & C9 & $>$ & C1 & $=$ & C5 & $=$ & C8 & $=$ & C6 & $=$ & $\mathrm{C} 7$ & $>$ & C3 & $=$ & $\mathrm{C} 4$ \\
\hline$\Gamma 4$ & D1 & $=$ & D6 & $=$ & D2 & $=$ & D9 & $=$ & D3 & $>$ & D4 & - & D8 & $>$ & D7 & $>$ & \\
\hline 5 & E2 & $=$ & E3 & $=$ & E6 & $=$ & E4 & $>$ & E1 & $=$ & E5 & & E9 & $=$ & E7 & $>$ & $E$ \\
\hline 16 & F6 & $>$ & F3 & $=$ & F1 & $=$ & F9 & $=$ & F5 & $>$ & F8 & - & F4 & $=$ & F7 & $>$ & $F$ \\
\hline T7 & G3 & $>$ & G6 & $=$ & G2 & $>$ & G1 & $>$ & G5 & $=$ & G7 & $=$ & G4 & $=$ & G9 & $>$ & G8 \\
\hline T8 & H3 & $>$ & $\mathrm{H} 2$ & $=$ & $\mathrm{H} 6$ & $>$ & $\mathrm{H} 1$ & $=$ & H5 & $=$ & $\mathrm{H} 8$ & $>$ & $\mathrm{H} 9$ & $=$ & $\mathrm{H} 4$ & $=$ & $\mathrm{H} 7$ \\
\hline T9 & 16 & $>$ & 13 & $=$ & I1 & $=$ & 12 & $=$ & 15 & $=$ & 19 & $>$ & 14 & $=$ & 17 & $>$ & 18 \\
\hline T10 & J3 & $>$ & J6 & $=$ & $\mathrm{J} 2$ & $=$ & J9 & $>$ & J5 & $=$ & J4 & $>$ & J8 & $=$ & $\mathrm{J} 7$ & $>$ & 1 \\
\hline
\end{tabular}

(it was adopted the level of significance of 0.05). The results were presented in the form of graphs and tables, making use of statistical programs SPSS (version 23), for the accomplishment of the descriptive and inferential statistics, as well as of the program STATA (version 14) for the confection of the graphs.

\section{RESULTS}

Initially an evaluation of the normality of the data was performed through the Kolmogorov-Smirnov test and from the graphical evaluation the distribution of the normal results was realized, making possible the use of the parametric tests. The ANOVA test was carried out among the evaluators (Table III), aiming to identify possible differences between the mean values obtained in the different analyzed materials, as well as the disposal of the respective materials in the sample cards. The results are presented below.

Table III. ANOVA test among the evaluators and disposition of the specimens in the sample cards.

\begin{tabular}{lllll}
\hline MATERIALS & \multicolumn{2}{c}{ Evaluators } & \multicolumn{2}{c}{ Sample cards } \\
& $\mathrm{F}$ & $\mathrm{p}$ & $\mathrm{F}$ & $\mathrm{p}$ \\
\hline GLACIER & 0.452 & 0.717 & 5.991 & $0.000^{* *}$ \\
LLIS & 0.846 & 0.478 & 2.970 & $0.012^{*}$ \\
LUNA & 0.608 & 0.614 & 16.736 & $0.000^{* *}$ \\
OPALLIS & 0.389 & 0.761 & 8.842 & $0.000^{* *}$ \\
POINT4 & 1.992 & 0.132 & 2.668 & $0.021^{*}$ \\
PREMISSA & 0.927 & 0.438 & 3.084 & $0.010^{*}$ \\
PREMIUM & 0.665 & 0.579 & 2.182 & 0.053 \\
TETRIC & 0.751 & 0.529 & 2.023 & 0.072 \\
ULTRAFILL & 0.059 & 0.981 & 6.541 & $0.000^{* *}$ \\
\hline
\end{tabular}


PEREIRA, A. L. C.; MATUDA, L. S. A.; LIMA, L. G.; SILVA, JOÃO, M. F. L.; MORAIS-SOUSA, L. K.; MATOS, J. D. M.; VASCONCELOS, J. E. L. E. \& MEDEIROS, C. R. Evaluation of the fluorescence of composite resins under an ultra violet light source. Int. J. Odontostomat., 12(3):252-261, 2018.

$F=$ Result of ANOVA test (fluorescence)

${ }^{*}$ Statistically significant differences considering $p<0.05$

** Statistically significant differences considering $p$ $<0.01$

Considering the results presented in Table III, it was observed that the way the test sample were exposed in the sample cards influenced the response given by the evaluators, since that a test sample (more fluorescent) when positioned next to another with lower fluorescence level, tends to be classified as less fluorescent, but if it were isolated it could have been classified as fluorescent as the others, that is, the comparative method influences the response.

The trademarks, Glacier, Luna, Opallis and Ultrafill did not present as much difference in relation of the placing of the specimens on the test cards. On the other hand, Llis, Point 4 and Premissa presented a certain difference in relation of the placement of the specimens. In contrast, Premium and Tetric N-Cream,

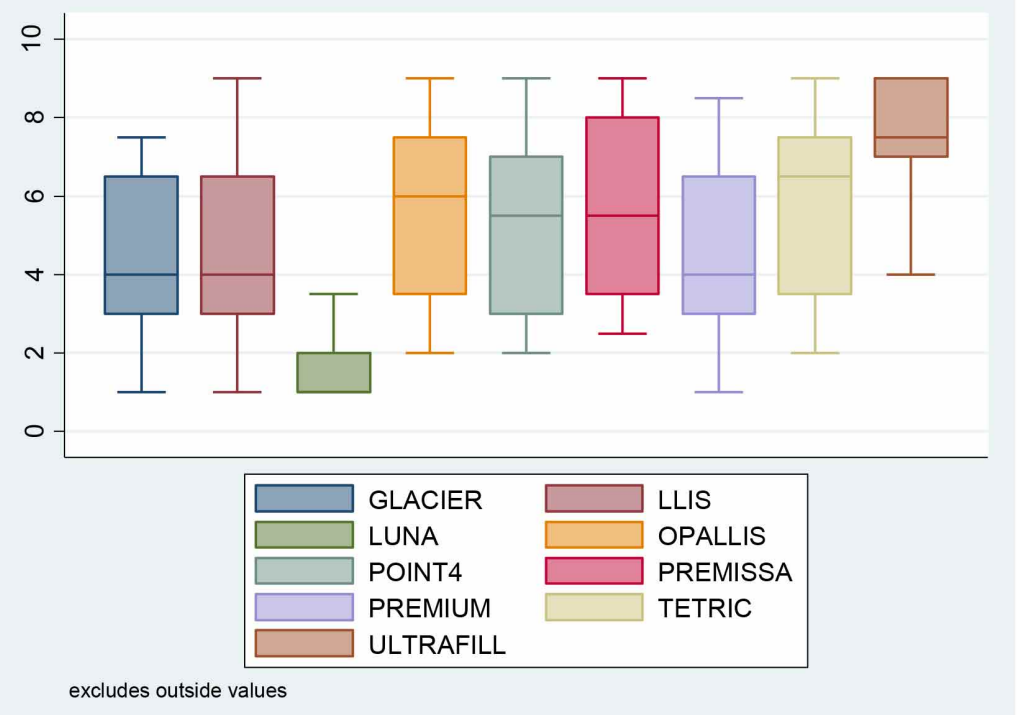

Fig. 12. Dispersion of the perceived fluorescence level scores of the tested materials. it the way they were positioned on the sample cards did not interfere with the response of the evaluators. This analysis took into consideration that $p<0.05$.

In relation to the dispersion of the scores presented by each material from the evaluations, a BoxPlot graph (Fig.12) is presented below. It is observed that the different materials tend to have similar dispersion, except for the Luna (SDI) and Ultrafill (Biodynamic) materials, respectively, the first with significantly lower results for the fluorescence level, while the second presented concentrated values in the higher scores. Luna (SDI) received values lower than the other materials, that is, it was evaluated as the least fluorescent of the 8 (eight) materials submitted to analysis, showing that all four evaluators indicated the same position of fluorescence.

In Table I, the mean values, standard deviation, maximum and minimum from the scores of each material are presented (Table IV).

* Groups which statistically significant differences were observed between the mean values from the Tukey Post Hoc test, considering $\mathrm{p}$ $<0.05$.

From Table IV, it was found that the Ultrafill composite resin was the most fluorescent of the all trademarks, while Luna was less fluorescent than all other composite resins subjected to analysis. In contrast, Tetric N-Cream and Opallis were higher in terms of fluorescence than Glacier. The composite resins, Premissa, Point 4, Premium and Llis, showed no statistically significant difference among them.

Table IV. Values obtained from the scores of each material.

\begin{tabular}{lllll}
\hline Material & Code & Mean \pm SD & Min-Max & Differences $^{*}$ \\
\hline ULTRAFILL & 9 & $7.3 \pm 1.6$ & $3-9$ & 1.2 .3 .4 .5 .6 .7 .8 \\
TETRIC & 8 & $5.9 \pm 2.0$ & $2-9$ & 1.3 .9 \\
OPALLIS & 4 & $5.6 \pm 2.1$ & $2-9$ & 1.3 .9 \\
PREMISSA & 6 & $5.6 \pm 2.2$ & $3-9$ & 3.9 \\
POINT 4 & 5 & $5.2 \pm 2.2$ & $2-9$ & 3.9 \\
LLIS & 2 & $4.7 \pm 2.1$ & $1-9$ & 3.9 \\
PREMIUM & 7 & $4.7 \pm 2.0$ & $1-9$ & 3.9 \\
GLACIER & 1 & $4.2 \pm 2.0$ & $1-7.5$ & 3.4 .8 .9 \\
LUNA & 3 & $1.9 \pm 1.7$ & $1-7$ & 1.2 .4 .5 .6 .7 .8 .9 \\
\hline
\end{tabular}


PEREIRA, A. L. C.; MATUDA, L. S. A.; LIMA, L. G.; SILVA, JOÃO, M. F. L.; MORAIS-SOUSA, L. K.; MATOS, J. D. M.; VASCONCELOS, J. E. L. E. \& MEDEIROS, C. R. Evaluation of the fluorescence of composite resins under an ultra violet light source. Int. J. Odontostomat., 12(3):252-261, 2018.

\section{DISCUSSION}

Fluorescence is understood as one of the indispensable optical properties to composite resin restorations in anterior teeth (Dalla Nora et al., 2013). The considerations of this property in dental structure and restorative materials can be seen in two different situations. During the day, due to the action of ultraviolet rays, this cause the phenomenon of dental fluorescence without visualization of human optics, nevertheless it makes it whiter and brighter. At night, in places that are illuminated by black light, this property becomes more evident, justifying the importance of knowing the fluorescent characteristics of restorative materials, so that the optical behavior of the restoration can be adapted (Busato et al., 2015).

The methodology utilized presents the bias of using test specimens and the non-application in the oral cavity, an understanding considered important, since the literature conceptualizes dental fluorescence around a wavelength between 430-450 nm (Lee et al., 2005), as well as Queiroz et al. (2010) and Yu \& Lee (2013) who showed that surface characteristics of test specimens can cause changes in the optical properties of materials, either by the form of storage or even by the time taken for analysis, due to the complete conversion of the monomers into polymers. In contrast, studies show the different forms of storage of test specimens and polishing concluding that the various types of polishing protocols associated with the type of storage do not cause significant changes in the intensity of the fluorescence of the test specimens (Dalla Nora et al.). However, if the analysis takes 21 (twenty-one) days after the preparation, tap water and ionized water as a form of storage of the bodies are not as stable when compared to artificial saliva, which is what demonstrated more stability (Söderholm et al., 1996).

The human eye is exposed to the range of light that forms the electromagnetic spectrum, which has the capacity to decompose at various wavelengths, but only a small band known as the "visible light spectrum" is able to sensitize the structures that form the retina, allowing that the process of color perception initiate (Sproull, 2001). However, the light source has numerous emission forms that differ in wavelength, so the perception of colors can suffer changes according to the amount of light that fall upon the object (Kim et al., 2016). This could be one of the possible variables in this research, but it was eliminated, since all the specimens were submitted to the same source of light and point of view.
During the analysis phase, the evaluators were instructed to wait one (1) min between the exchanges of the sample cards, due to the tendentious fluorescent effect caused in human optics. Carron \& Guimarães (1997) reported that lamps are classified as artificial primary lights, while those capable of producing and emitting light are the primary sources of light, respectively. The first one, being the black light used in the analysis phase and the second one, being the test samples, would require an environment with red light to keep the evaluator during the change of the test card and not just wait one minute. Since that red light causes a state of alertness and prevents drowsiness, as well as having a reverse effect on ultraviolet light, while black light causes toxins to build up inside the eye, because the receptors need to work beyond normal to capture the blue light, resulting in a greater irritation of the eye (McPhee; Ahmad, 1999).

Regarding the research, the composite resin Ultrafill (Biodynamics) was statistically significant the most fluorescent of all the composites evaluated, whereas Luna resin (SDI) was statistically less fluorescent than all the others, followed by the Tetric $\mathrm{N}$-Cream composite (Ivoclar). On the other hand, Point 4 (Kerr) is less fluorescent than Ultrafill (Biodynamic), Premise (Kerr) and Tetric N-Cream (Ivoclar), also said as a material with fluorescent properties suitable for aesthetic restoration, agreeing with the results obtained by Busato et al. (2006), in relation to Tetric N-Cream (Ivoclar) and Point 4 (Kerr). The composite resin Point 4 (Kerr), Premium (Coltene) and Llis (FGM) presented an equivalent fluorescence level and were considered less fluorescent than Ultrafill (Biodynamic), Premissa (Kerr) and Tetric N-Cream (Ivoclar), agreeing with the results obtained by Busato et al. (2015) and Jablonski et al. (2014).

The results found in this research disagree with those found in another study, because it affirmed that all the composite resins available for use in dentistry have a high level of fluorescence, whereas the referenced research showed that the trademarks differ in terms of fluorescence and may even be considered equal with each other (Meller \& Klein).

The results showed that the disposition of the samples in the sample cards can influence the responses provided by the evaluators, since that a test specimen that emits high level of fluorescence when positioned next to one that has medium fluorescence can be considered non aesthetic; The opposite may also justify such interference, since the positioning of 
PEREIRA, A. L. C.; MATUDA, L. S. A.; LIMA, L. G.; SILVA, JOÃO, M. F. L.; MORAIS-SOUSA, L. K.; MATOS, J. D. M.; VASCONCELOS, J. E. L. E. \& MEDEIROS, C. R. Evaluation of the fluorescence of composite resins under an ultra violet light source. Int. J. Odontostomat., 12(3):252-261, 2018.

the black light inside the camera may reflect more light on one part of the sample card than on the other, although Baeza et al. (2002) also used the visual method and arrangement on sample cards during his studies.

The research also did not compare the composite resins with a dental structure, which could show that certain composites can have ideal fluorescent properties for a given dental structure, even though it is not considered by the referring study as the most fluorescent, a comparison was made by Villaroel (2004) and it explained the relevance of this comparative study.

\section{CONCLUSION}

It can be concluded from this study that: The nine commercial brands of resin composites analyzed in this study presented different levels of fluorescence, however, with similar dispersion when compared to each other.

It was concluded that the Ultrafill resin (Biodynamic) was considered the most fluorescent among the eight that was analysed, since that of the ten sample cards prepared and displayed at the time of the test, all four evaluators pointed this resin with the most fluorescent, the same happened to Luna (SDI), but it was denoted as the less fluorescent. The composite resin Tetric N-Cream and Opallis were superior in terms of fluorescence relative to Glacier, whereas, Premissa, Point 4, Premium and Llis, did not present significant differences between them.

Therefore, in sequence of decreasing fluorescence observed, according to the statistical data, we had the following order: Ultrafill, Tetric N-Cream, Opallis, Premissa, Point 4, Llis, Premium, Glacier and Luna.

PEREIRA, A. L. C.; MATUDA, L. S. A.; LIMA, L. G.; SILVA, JOÃO, M. F. L.; MORAIS-SOUSA, L. K.; MATOS, J. D. M.; VASCONCELOS, J. E. L. \& MEDEIROS, C. R. Evaluación de la fluorescencia de resinas compuestas bajo una fuente de luz ultravioleta. Int. J. Odontostomat., 12(3):252-261, 2018.

RESUMEN : El objetivo de esta investigación es comparar la fluorescencia de diferentes marcas registradas de resinas compuestas bajo luz ultravioleta, indicando a través de las características ópticas los materiales de restauración que mejor imitan las propiedades de la fluorescencia dental. En este estudio, se evaluaron nueve marcas registradas de resina de color EA2, y se prepararon diez muestras de prueba para cada material, totalizando noventa especímenes. Las muestras se produjeron a partir de una matriz de aluminio bipartita $(10 \times 2 \mathrm{~mm})$, y luego se almacenaron durante 24 $\mathrm{h}$ en tubos de películas radiográficas, se sumergieron en agua destilada y después de $48 \mathrm{~h}$ se pulieron. Se utilizó un estudio de tipo ciego (cuatro evaluadores) y las muestras se analizaron en una cámara de madera oscura donde se acoplaron dos lámparas negras. En la fase de recolección de datos, se utilizaron las pruebas de normalidad KolmogorovSmirnov, ANOVA y Post Hoc de Tukey (adoptaron un nivel de significancia de 0,05 ). Se observó que la resina compuesta de la marca registrada Ultrafill era más fluorescente y la marca Luna fue estadísticamente menos fluorescente que todos los demás materiales, mientras que Opallis y Tetric eran superiores a Glacier. No hubo diferencias estadísticamente significativas entre las resinas compuestas Premissa, Point 4, Llis y Premium.

PALABRAS CLAVE: fluorescencia, estética dental, rayos ultravioleta.

\section{REFERENCES}

Ahmad, I. Three-dimensional shade analysis: perspectives of color--Part I. Pract. Periodontics Aesthet. Dent., 11(7):789-96, 1999.

Baeza, W. R.; Ribera, C.; Ehrmantraut, N. M. \& Bader Matta, M. Fluorescencia de resinas compuestas de obturación directa. Rev. Fac. Odontol. Univ. Chile, 20(2):54-60, 2002.

Benedict, H. C. A note on the fluorescence of teeth in ultra-violet rays. Science, 67(1739):442, 1928

Busato, A. L. S.; Reichert, L. A.; Valin, R. R.; Arossi, G. A. \& da Silveira, C. M. Comparação de fluorescência entre resinas compostas restauradoras e a estrutura dental hígida - In vivo. Rev. Odontol. Araçatuba, 27(2):142-7, 2006.

Busato, P. M. R.; Saggin, P. G.; Camilotti, V.; Mendonça, M. J. \& Busato, M. C. A. Avaliação da fluorescência das resinas compostas para esmalte e dentina de diferentes marcas comerciais. Polímeros, 25(2):200-4, 2015.

Dalla Nora, Â.; Bueno, R. P. R. \& Pozzobon, R. T. Intensidade de fluorescência em resina composta: influência do polimento superficial e dos meios de armazenagem. Rev. Odontol. UNESP, 42(2):104-9, 2013.

Jablonski, T.; Takahashi, M. K.; Brum, R. T.; Rached, R. N. \& Souza, E. M. Comparative study of the fluorescence intensity of dental composites and human teeth submitted to artificial aging. Gen. Dent., 62(1):37-41, 2014.

Kim, B. R.; Kang, S. M.; Kim, G. M. \& Kim, B. I. Differences in the intensity of light-induced fluorescence emitted by resin composites. Photodiagnosis Photodyn. Ther., 13:114-9, 2016.

Kosovel, Z. \& Weber, K. Natural fluorescence of human teeth. Zahn Mund Kieferheilkd. Zentralbl., 64(1):32-40, 1976.

Lee, Y. K.; Lu, H. \& Powers, J. M. Fluorescence of layered resin composites. J. Esthet. Restor. Dent., 17(2):93-100, 2005.

Lefever, D.; Mayoral, J. R.; Mercade, M.; Basilio, J. \& Roig, M. Optical integration and fluorescence: a comparison among restorative 
PEREIRA, A. L. C.; MATUDA, L. S. A.; LIMA, L. G.; SILVA, JOÃO, M. F. L.; MORAIS-SOUSA, L. K.; MATOS, J. D. M.; VASCONCELOS, J. E. L. E. \& MEDEIROS, C. R. Evaluation of the fluorescence of composite resins under an ultra violet light source. Int. J. Odontostomat., 12(3):252-261, 2018.

materials with spectrophotometric analysis. Quintessence Int., 41(10):837-44, 2010.

McLaren, E. A. Luminescent veneers. J. Esthet. Dent., 9(1):3-12, 1997.

McPhee, E. R. Extrinsic coloration of ceramometal restorations. Dent. Clin. North Am., 29(4):645-66, 1985.

Meller, C. \& Klein, C. Fluorescence properties of commercial composite resin restorative materials in dentistry. Dent. Mater. J., 31(6):916-23, 2012.

Melo, T. S.; Kano, P. \& Araujo Junior, E. M. Avaliação e reprodução cromática em Odontologia Restauradora Parte II: a dinâmica da luz nos dentes naturais. Clin. Int. J. Braz. Dent., 1(4):295-303, 2005.

Monsénégo, G.; Burdairon, G. \& Clerjaud, B. Fluorescence of dental porcelain. J. Prosthet. Dent., 69(1):106-13, 1993.

Panzeri, H.; Fernandes, L. T. \& MinellI, C. J. Spectral fluorescence of direct anterior restorative materials. Aust. Dent. J., 22(6):45861, 1977.

Priest, G. \& Lindke, L. Tooth color selection and characterization accomplished with optical mapping. Pract. Periodontics Aesthet. Dent., 12(5):497-503, 2000.

Queiroz, R. S.; Bandéca, M. C.; Calixto, L. R.; Gaiao, U.; Cuin, A. \& Porto-Neto, S. T. Influence of the light-curing unit, storage time and shade of a dental composite resin on the fluorescence. Laser Phys., 20(7):1647-53, 2010.

Rudd, K. D.; Morrow, R. M.; Welker, W. A. \& Jendresen, M. D. Some uses of fluorescence in prosthodontics. J. Prosthet. Dent., 18(6):543-9, 1967.

Sensi, L. G. Fluorescence of composite resins: Clinical considerations. Quintessence Dent. Technol., 29(1):43-53, 2006.

Söderholm, K. J.; Mukherjee, R. \& Longmate, J. Filler leachability of composites stored in distilled water or artificial saliva. J. Dent. Res., 75(9):1692-9, 1996.

Sproull, R. C. Color matching in dentistry. Part II. Practical applications of the organization of color. 1973. J. Prosthet. Dent., 86(5):458-64, 2001.

Terry, D. A.; Geller, W.; Tric, O.; Anderson, M. J.; Tourville, M. \& Kobashigawa, A. Anatomical form defines color: function, form, and aesthetics. Pract. Proced. Aesthet. Dent., 14(1):59-67, 2002.

Vanini, L. \& Mangani, F. M. Determination and communication of color using the five color dimensions of teeth. Pract. Proced. Aesthet. Dent., 13(1):19-26, 2001.

Villarroel, M.; Jorquera, C.; Gomes, O. M. M. \& Gomes, J. C. Fluorescência: uma contribuição na vitalidade natural do dente humano. Rev. Iberoam. Odontol. Estet. Dent., 3(12):397-406, 2004.

Yu, B. \& Lee, Y. K. Comparison of stabilities in translucency, fluorescence and opalescence of direct and indirect composite resins. Eur. J. Esthet. Dent., 8(2):214-25, 2013.
Corresponding author:

John Eversong Lucena de Vasconcelos

D.D.S.; M.D.; Ph.D.

Professor of Oral Implantology

Department of Dentistry

Centro Caririense de Pós-Graduação CECAP

Rua Sulino Duda, 113, Triangulo - Juazeiro do Norte

CE - CEP 63041 - 185

BRAZIL

Email: larisse.c_19@hotmail.com matosjefferson19@gmail.com

Received: 30-04-2018

Accepted: 09-06-2018 